\title{
Genetic Analysis for Growth and Yield Parameters in Common Bean (Phaseolus vulgaris L.)
}

\author{
K. Gangadhara ${ }^{1 *}$, L.P. Yadav ${ }^{1}$, Raj $\operatorname{Kumar}^{2}$ V.V. Apparao ${ }^{1}$ and R. Selvakumar ${ }^{3}$ \\ ${ }^{1}$ Horticulture-Vegetable Science, ICAR-CIAH, RS-CHES, Vejalpur, Godhra, Gujarat, India \\ ${ }^{2} S M S$ (Horticulture), KVK, Panchamahal, Gujarat, India \\ ${ }^{3}$ ICAR-Central Institute of Temperate Horticulture, KD Farm, Old Air Field, \\ Rangreth-190 007, Srinagar, Jammu and Kashmir, India
}

*Corresponding author

\section{A B S T R A C T}

\begin{tabular}{|l|}
\hline K e y w o r d s \\
$\begin{array}{l}\text { French bean, } \\
\text { Additive, Non } \\
\text { additive, Narrow } \\
\text { sense heritability }\end{array}$ \\
\hline Article Info \\
\hline $\begin{array}{l}\text { Accepted: } \\
\text { 12 May } 2019 \\
\text { Available Online: } \\
\text { 10 June } 2019\end{array}$ \\
\hline
\end{tabular}

The genetic analysis was carried in a $6 \times 6$ half diallel breeding programme of common bean for thirteen yield and yield attributing parameters. Both additive and non-additive genetic components were responsible in the genetic system controlling yield and its component characters. The additive (D) genetic variance was significant for Days to first flowering, Days to fifty per cent flowering, Days to maturity and pod length. Dominant components $\left(\mathrm{H}_{1}\right.$ and $\left.\mathrm{H}_{2}\right)$ were showed significantly difference for plant height at 30 DAS and 60 DAS, number of branches at 30 and 60 DAS, days to first flowering, days to fifty per cent flowering, days to maturity, pod length, pod weight, number of seeds per plant and hundred seed weight. The high narrow sense heritability was recorded for pod length (0.683) followed by pod weight (0.381) and days to first flowering (0.353). It is evidenced that both additive and non-additive gene effects are involved in the genetic control of the traits. So both gene effects should be considered when developing superior lines.

\section{Introduction}

French bean (Phaseolus vulgaris L., 2n=22, family-Leguminosae), is a one of the most important leguminous vegetables. It is grown for the tender vegetable, shelled green beans and dry beans. In India it is grown for tender vegetable, while in the USA and European countries it is grown for processing in large quantities. Green beans are found in two major groups, bush beans and pole beans. Bush beans are short plants, growing to approximately two feet in height, without requiring supports. They generally reach maturity and produce all of their fruit in a relatively short period of time. Being a short duration crop French bean can be grown under different cropping patterns of hills and plains of India. In India, it is mainly grown in Himachal Pradesh, Punjab, Haryana, Uttar Pradesh, Bihar, Gujarat, Madhya Pradesh, Maharashtra, Karnataka, Andhra Pradesh and Tamil Nadu.

French beans furnish a large portion of the protein needs of low and middle class families 
of India which is due to its high nutritive value, good taste and wide range of use. Compare to other leguminous vegetable crops, limited information regarding the gene action controlling the expression of characters of French bean has been available in India. In general yield and yield attributes are governed by polygenes and their inheritance system is complex. For improvement of any plant character through hybridization, it is necessary to understand the nature of gene action and genetic architecture of the donor parents for that character. Diallel analysis helps in the selection of suitable parents for hybridization as well as in the choice of appropriate breeding procedure. Hence, the present study was conducted to find out the information on nature and magnitude of gene action for yield and yield attributing parameters.

\section{Materials and Methods}

The six parents namely Arka komal, Arka Suvidha, Black Seeded, Gokak Local, Arabhavi Local and Ring bean were chosen as a parental lines in a diallel breeding design without reciprocal and developed fifteen hybrid combinations (Table 1). The study was conducted at Kitture Rani Channamma College of Horticulture, Arabhavi, University of Horticultural Sciences, Bagalkot. The experiment was laid out in a randomized complete block design (RCBD) with two replications. Ridges and furrows were opened at a distance of $30 \mathrm{~cm}$. Seeds of each genotype were dibbled at a distance of $10 \mathrm{~cm}$ in a row. Observations were recorded on the five plants chosen at random in each cross and in each replication. The mean of five plants were taken for analysis in each genotype and observations were recorded.

Hybridization was done in such a way that, the flower buds of female parents were selected and emasculated on the previous day evening. The flower buds of female parent which were emasculated were used for crossing and pollination was carried out between $6 \mathrm{AM}$ to 7:30 AM by using pollens of desired male parent after pollination the female buds were tagged with details of male parent and date of pollination. The crossed pods were harvested separately at full maturity stage. Seeds were hand extracted and preserved in paper bags, labelled with the details of cross. The genetic components of variation were estimated following numerical and graphical approaches of Hayman (1954a, 1954b) and Jinks (1954) and explained through a worked example by Aksel and Johnson (1963).

\section{Results and Discussion}

The genetic components of variation like $\mathrm{D}$ (variation due to additive effect), $\mathrm{F}$ (mean of the covariance of additive and dominant effect over arrays), $\mathrm{H}_{1}$ and $\mathrm{H}_{2}$ (dominance genetic effects), $\mathrm{h}^{2}$ (sum of dominance effect over all loci), E (Environmental component of variation) with their respective standard errors and their ratios and differences viz., $\left(\mathrm{H}_{1} / \mathrm{D}\right)^{1 / 2}$ (mean degree of dominance), $\mathrm{H}_{2} / 4 \mathrm{H}_{1}$ (the proportion of genes with positive and negative effects on the parents), $\mathrm{h}^{2} / \mathrm{H}_{2}$ (number of genes groups controlling that character and exhibiting dominance) and heritability in narrow sense are discussed (Table 2) for all the 13 traits.

The additive (D) genetic variance was significant for Days to first flowering, Days to fifty per cent flowering, Days to maturity, pod length and for remaining characters it was non-significant. The similar results were given by Barelli et al., (2000), Hasan et al., (2005) and Salem (2009). The sum of dominance effect over all loci $\left(\mathrm{h}^{2}\right)$ was significant for number of branches at 60 DAS, Days to first flowering, days to fifty per cent flowering, pod weight, number of seeds per 
plant, hundred seed weight and for rest of the characters it was non-significant. The similar findings were given by Hasan et al., (2005) and Vaghela et al., (2009). The highest $\mathrm{h}^{2}$ value (8794.199) for number of seeds per plant and lowest value $(0.597)$ for pod weight was recorded. Dominant components $\left(\mathrm{H}_{1}\right.$ and $\mathrm{H}_{2}$ ) were showed significantly difference for plant height at 30 DAS and 60DAS, number of branches at 30 and 60DAS, days to first flowering, days to fifty per cent flowering, days to maturity, pod length, pod weight, number of seeds per plant and hundred seed weight but $\mathrm{H}_{1}$ for pod length it was nonsignificant. The highest (2918.431) and lowest (0.904) $\mathrm{H}_{1}$ value for number of seeds per palnt and the highest (2789.877) and lowest $(0.755) \mathrm{H}_{2}$ value for number of seeds per plant was recorded. These results were agreed with Hasan et al., (2005) and Iqbal et al., (2010). This shows the importance of additive dominance and type of gene action in controlling the expression of these characters. Magnitude of dominance effect is more compare to the additive component, hence solution may be practiced in the segregating population and also intermating of the selected plants in segregating population or recurrent selections may be practiced to improve the yield.

The degree of dominance $\left(\mathrm{H}_{1} / \mathrm{D}\right){ }^{1 / 2}$ was more than one for all the characters which indicates all these characters were had over dominance except pod length which was had partial dominance. The same findings were reported by Hasan et al., (2005), Iqbal et al., (2010), Senthilkumar (2011), and Maluf et al., (1989). If the ratio of degree of dominance component is zero, it indicates no dominance, ratio is greater than zero and less than one indicates there is a partial dominance, if this ratio is more than one means there is a over dominance. The proportion of genes with positive and negative effects in the parent $\left(\mathrm{H}_{2} / 4 \mathrm{H}_{1}\right)$ was equal to 0.25 for plant height 30 and 60 DAS, number of branches at 60 DAS, days to first and fifty per cent flowering, days to maturity, pod weight, and number of seeds per plant. It indicates that positive and negative allels were symmetrically distributed. If this ratio is showing less than 0.25 indicates unequal distribution of genes with positive and negative effect.

Table.1 List of $F_{1}$ Hybrids of common bean in the half diallel fashion

\begin{tabular}{|c|c|c|c|c|c|}
\hline S. $\mathbf{N}$. & $\begin{array}{c}\text { Cross } \\
\text { number }\end{array}$ & HYBRIDS & S. N. & $\begin{array}{c}\text { Cross } \\
\text { number }\end{array}$ & HYBRIDS \\
\hline 1 & $1 \times 2$ & Arka Komal x Arka Suvidha & 9 & $2 \times 6$ & Arka Suvidha x Ring Beans \\
\hline 2 & $1 \times 3$ & Arka Komal x Black Seeded & 10 & $3 \times 4$ & $\begin{array}{l}\text { Black Seeded x Gokak } \\
\text { Local }\end{array}$ \\
\hline 3 & $1 \times 4$ & Arka Komal x Gokak Local & 11 & $3 \times 5$ & $\begin{array}{l}\text { Black Seeded x Arabhavi } \\
\text { Local }\end{array}$ \\
\hline 4 & $1 \times 5$ & $\begin{array}{c}\text { Arka Komal x Arabhavi } \\
\text { Local }\end{array}$ & 12 & $3 \times 6$ & Black Seeded x Ring Beans \\
\hline 5 & $1 \times 6$ & Arka Komal x Ring Beans & 13 & $4 \times 5$ & $\begin{array}{c}\text { Gokak Local x Arabhavi } \\
\text { Local }\end{array}$ \\
\hline 6 & $2 \times 3$ & Arka Suvidha x Black Seeded & 14 & $4 \times 6$ & Gokak Local x Ring Beans \\
\hline 7 & $2 \times 4$ & Arka Suvidha x Gokak Local & 15 & $5 \times 6$ & $\begin{array}{c}\text { Arabhavi Local x Ring } \\
\text { Beans }\end{array}$ \\
\hline 8 & $2 \times 5$ & $\begin{array}{c}\text { Arka Suvidha x Arabhavi } \\
\text { Local }\end{array}$ & & & \\
\hline
\end{tabular}


Table.2 Estimates of genetic components of variation and proportion and differences for yield and yield contributing characters in French bean (Phaseolus vulgaris L.)

\begin{tabular}{|c|c|c|c|c|c|c|c|c|}
\hline Sl. No & $\begin{array}{c}\text { Genetic } \\
\text { components }\end{array}$ & $\begin{array}{c}\text { Plant height } \\
\text { at } 30 \text { DAS } \\
(\mathrm{cm})\end{array}$ & $\begin{array}{c}\text { Plant height } \\
\text { at } 60 \text { DAS } \\
(\mathrm{cm})\end{array}$ & $\begin{array}{l}\text { Number of } \\
\text { branches at } \\
30 \text { DAS }\end{array}$ & $\begin{array}{c}\text { Number of } \\
\text { branches at } \\
60 \text { DAS }\end{array}$ & $\begin{array}{l}\text { Days to first } \\
\text { flowering }\end{array}$ & $\begin{array}{c}\text { Days to } \\
50 \% \\
\text { flowering }\end{array}$ & $\begin{array}{c}\text { Days to } \\
\text { maturity }\end{array}$ \\
\hline 1 & $\mathrm{D}$ & -1.973 & -3.684 & -0.139 & 0.354 & $3.05 *$ & $2.473 *$ & $4.967^{*}$ \\
\hline 2 & $\mathrm{~F}$ & 2.46 & -2.469 & 0.378 & 1.113 & 2.228 & $2.251 *$ & 4.722 \\
\hline 3 & $\mathrm{H}_{1}$ & $144.781 *$ & $157.173 *$ & $3.212 *$ & $5.647 *$ & $6.827 *$ & $3.062 *$ & $4.756^{*}$ \\
\hline 4 & $\mathrm{H}_{2}$ & $130.016^{*}$ & $150.124 *$ & $2.23 *$ & $4.802 *$ & $5.784 *$ & $2.456^{*}$ & $13.081 *$ \\
\hline 5 & $h^{2}$ & 29.841 & -1.563 & 1.003 & 14.576 & $11.844^{*}$ & $1.958^{*}$ & 0.475 \\
\hline 6 & $\mathrm{E}$ & 9.358 & 11.417 & 0.27 & 0.337 & 0.265 & $0.251^{*}$ & $1.833^{*}$ \\
\hline 7 & $\left(\mathrm{H}_{1} / \mathrm{D}\right)^{1 / 2}$ & 8.565 & 6.532 & 4.8 & 3.996 & 1.496 & 1.113 & 1.724 \\
\hline 8 & $\mathrm{H}_{2} / 4 \mathrm{H}_{1}$ & 0.225 & 0.239 & 0.174 & 0.213 & 0.212 & 0.2 & 0.222 \\
\hline 9 & $\mathrm{~h}^{2} / \mathrm{H}_{2}$ & 0.23 & -0.01 & 0.45 & 3.036 & 2.048 & 0.797 & 0.036 \\
\hline 10 & $\begin{array}{l}\mathrm{h}^{2} \text { (narrow } \\
\text { sense) }\end{array}$ & 0.11 & 0.056 & 0.219 & 0.027 & 0.353 & 0.324 & 0.158 \\
\hline
\end{tabular}

${ }^{*} \mathrm{P}<0.05,{ }^{* *} \mathrm{p}<0.01$ 
Table.2 Continued.

\begin{tabular}{|c|c|c|c|c|c|c|c|}
\hline Sl. No. & Genetic components & $\begin{array}{l}\text { Pod length } \\
\text { (cm) }\end{array}$ & $\begin{array}{c}\text { Pod weight } \\
\text { (g) }\end{array}$ & $\begin{array}{c}\text { Number of } \\
\text { pods per plant }\end{array}$ & $\begin{array}{c}\text { Number of } \\
\text { seeds per plant } \\
\text { (g) }\end{array}$ & $\begin{array}{l}100 \text { seed weight } \\
(\mathrm{g})\end{array}$ & $\begin{array}{l}\text { Green pod } \\
\text { yield per plant } \\
\text { (g) }\end{array}$ \\
\hline 1 & $\mathrm{D}$ & $3.590 *$ & 0.012 & -11.642 & -10.875 & 1.639 & -1362.024 \\
\hline 2 & $\mathrm{~F}$ & 0.416 & -0.204 & -12.594 & 16.273 & 5.411 & -1403.741 \\
\hline 3 & $\mathrm{H}_{1}$ & $3.581 *$ & $0.904 *$ & 41.451 & $2918.431 *$ & $49.662 *$ & 2313.145 \\
\hline 4 & $\mathrm{H}_{2}$ & 2.673 & 0.755 & 25.051 & $2789.877 *$ & $38.572 *$ & 1733.02 \\
\hline 5 & h2 & 0.559 & $0.597 *$ & 21.547 & $8794.199 *$ & $74.741^{*}$ & 384.015 \\
\hline 6 & $\mathrm{E}$ & 0.281 & 0.108 & $16.333^{*}$ & $197.866^{*}$ & 0.727 & $1611.147 *$ \\
\hline 7 & $\left(\mathrm{H}_{1} / \mathrm{D}\right)^{1 / 2}$ & 0.999 & 8.648 & 1.887 & 16.382 & 5.504 & 1.303 \\
\hline 8 & $\mathrm{H}_{2} / 4 \mathrm{H}_{1}$ & 0.187 & 0.209 & 1.510 & 0.239 & 1.857 & 0.187 \\
\hline 9 & $h^{2} / \mathrm{H}_{2}$ & 0.209 & 0.790 & 0.86 & 3.152 & 1.938 & 0.222 \\
\hline 10 & $\mathrm{~h}^{2}$ (narrow sense) & 0.683 & 0.381 & 0.277 & 0.054 & 0.261 & 0.132 \\
\hline
\end{tabular}


The results were agreement with the reports of Hasan et al., (2005), Senthilkumar (2011) and Maluf et al., (1989). The negative effects of alleles in parents were compensated by positive alleles in the hybrid resulting over dominance. Hence, selection of parent with high positive alleles, dominant genes manifests dominance in hybrid. Number of alleles or allelic groups and narrow sense heritability was showing non-significant for all the characters. The high narrow sense heritability was recorded for pod length (0.683) followed by pod weight $(0.381)$ and days to first flowering (0.353) same results were given by Hasan et al., (2005). Higher $\mathrm{h}^{2}$ was noticed for pod length compared with additive variance; hence this character can be improved through selection.

It is evidenced that both additive and nonadditive gene effects are involved in the genetic control of the traits. So both gene effects should be considered when developing superior lines. French bean is self-pollinated crop, homozygous and thus they do not make use of the dominance effects of genes at individual loci. Therefore, crosses involving genotypes with high GCA estimates are required for the selection in advanced generation.

\section{References}

Aksel, R., and Johnson, L.P.V.1963. Analysis of diallel cross - A worked example. Adv. Front. Pl. Sci., 2: 37 -53.

Barelli, M. A. A., Vidigal, M. C. G, Junior, A. $\mathrm{T}$ and Scapim, C. A.2000.combining ability among six common bean cultivars adapted to North West of Parana state, Brazil. Bragantia Campinas, 59: 159-164.

Hasan, M. N., Islam, A. K. M. A, Mian, M. A. $\mathrm{K}$ and Hossain, T. 2005. Combining ability analysis in the $\mathrm{F}_{2}$ generation of a $7 \times 7$ half diallel cross of french bean (Phaseolus vulgaris L.). Bangladesh J. Life Sci., 17 (2):75-81.

Hayman, B., 1954a. The analysis of variance of diallel tables. Biometrics 10: 235244.

Hayman, B.I., 1954b. The theory and analysis of diallel crosses. Genetics, 39: 789809.

Iqbal, A. M., Nehvi, F. A, Wani, S. A, and Dar, S. A.2010. Diallel analysis in rajmash. J. Food Leg., 23 (3\&4): 208211.

Jinks, J. L., 1954. The analysis of continuous variation in a diallel cross in Nicotiana rustica varieties. Genetics, 39: 767-788.

Maluf, W.R., Miranda, J. E. C. and Rossi, F. P. E. 1989. Genetic analysis of components of fruit size and shape in a diallel cross of tomato cultivars. Brasil Genet., 12(4): 819-831.

Salem, S. A., 2009. Heterosis and combining ability in diallel cross of eight faba bean (Vicia faba L.) genotypes. Asian J. Crop Sci., 1 (2): 66-76.

Senthilkumar, N., 2011.Genetic analysis of a diallel cross for fruit yield and its component traits in okra [Abelmoschus esculentus (L.) Moench]. Plant Archives, 11(2): 719-721.

\section{How to cite this article:}

Gangadhara, K., L.P. Yadav, Raj Kumar, V.V. Apparao and Selvakumar, R. 2019. Genetic Analysis for Growth and Yield Parameters in Common Bean (Phaseolus vulgaris L.). Int.J.Curr.Microbiol.App.Sci. 8(06): 1550-1555. doi: https://doi.org/10.20546/ijcmas.2019.806.186 